\title{
Faktor Penggelapan Pajak, Interaksi Fiskus dengan Wajib Pajak dan Kepatuhan Pajak di Kantor Pelayanan Pajak Pratama Bogor
}

\author{
Surono $^{1}$, Nur Hidayat ${ }^{2}$ \\ ${ }^{1}$ Universitas Pancasila, Jl. Srengseng Sawah, Jagakarsa, Jakarta Selatan 12640 \\ ${ }^{2}$ Universitas Jenderal Achmad Yani, Jl. Terusan Jenderal Gatot Subroto, PO.BOX 807 Bandung, 40285
}

\section{INFO ARTIKEL}

\section{JEL Classification: \\ H26}

\section{Keywords:}

tax compliance, tax evasion factors and interactions with the tax authorities taxpayer.

\section{A B S T R A C T}

This study influence of tax evasion and the interaction with the tax authorities on the tax compliance of taxpayers. The population in this study is the individual taxpayer (WPOP) in Bogor district. Sampling was done by the method of proportional sampling. The number of samples is determined 200. Primary data collection method used was by questionnaire (questioner). Data analysis tool used in this study is SEM with Lisrel 8:54. Results show that, the factors that significantly affect tax evasion on Tax compliance, interaction with the tax authorities Taxpayer significant effect on Tax compliance. Factors tax authorities of tax evasion and interaction with taxpayers collectively significant effect on tax compliance.

\section{A B S T R A K}

Penelitian ini bertujuan untuk menguji pengaruh faktor penggelapan pajak dan interaksi fiskus dengan wajib pajak terhadap kepatuhan pajak. Populasi dalam penelitian ini adalah Wajib Pajak Orang Pribadi (WPOP) yang ada di kabupaten Bogor. Pengambilan sampel dilakukan dengan metode proportional sampling. Jumlah sampel ditentukan 200 orang. Metode pengumpulan data primer yang dipakai adalah dengan metode kuesioner. Alat analisis data yang digunakan dalam penelitian ini adalah structural equation modeling dengan Lisrel 8.54. Hasil analis menunjukkan faktor penggelapan pajak berpengaruh signifikan terhadap kepatuhan pajak, interkasi fiskus dengan wajib pajak berpengaruh signifikan terhadap kepatuhan pajak.

\section{Pendahuluan}

Penggelapan Pajak (tax evasion) oleh Wajib Pajak adalah salah satu faktor yang dapat mempengaruhi kepatuhan Pajak. Penggelapan Pajak oleh Wajib Pajak tersebut disebabkan oleh beberapa faktor yaitu: pengenaan sanksi pajak tidak berat, lemahnya penegakan hukum, manfaat dan biaya, kecil kemungkinan perbuatannya terungkap dan bila terungkap masalahnya dapat diselesaikan (Hutagaol, 2010). Wajib Pajak akan melakukan Penghindaran pajak secara ilegal/penggelapan pajak (tax evasion) yaitu wajib pajak tidak melaporkan secara utuh kekayaan dan 
penghasilannya yang semestinya kena pajak. Sebagaimana hal ini terjadi karena kurangnya pengawasan dari fiskus. Alm et.al, (2001) menyebutkan bahwa kemungkinan Wajib Pajak akan diperiksa justru akan berpengaruh dari pada sanksi administrasi dan pidana karena wajib pajak mengetahui bahwa otoritas pajak tidak akan melakukan seleksi secara acak kepada wajib pajak yang akan diperiksa, akan tetapi menggunakan informasi dari SPT yang disampaikan wajib pajak untuk menentukan pemeriksaan. Selain sanksi administrasi dan kemungkinan dilakukan audit, yang menjadi alasan mengapa wajib pajak enggan untuk melakukan penghindaran pajak atau pengelakan pajak adalah kualitas layanan publik yang mereka peroleh serta kemungkinan wajib pajak dalam melakukan kewajiban perpajakannya dengan didukung oleh rendahnya biaya-biaya maupun pungut apabila mereka melakukan kewajiban secara benar dan tepat.

Disamping faktor penggelapan pajak tersebut di atash faktor yang dapat meningkatkan kepatuhan pajak adalah budaya pajak salah satu indikatornya interaksi antara fiskus dengan
Wajib Pajak (Widodo, 2010). Hubungan fiskus dengan wajib pajak merupakan hubungan administratif dalam arti hubungan secara fungsi dan tanggung jawab. Interaksi fiskus dengan Wajib Pajak dapat diukur melalui keramahan petugas dalam melayani Wajib Pajak, kemampuan petugas pajak dalam melayani permasalahan perpajakan, ketanggapan dan kecepatan petugas dalam melayani permasalahan perpajakan dan perhatian petugas dalam melayani permasalahan perpajakan.

Dalam Kepatuhan pajak itu sendiri di Kabupaten Bogor KPP Cibinong dan KPP Cileungsi secara khusus, hingga tahun 2011 terdapat k 197.434 Wajib Pajak Orang Pribadi (WP OP) yang terdaftar. Namun dari jumlah tersebut yang menyampaikan SPT Tahun Wajib Pajak Orang Pribadi (WP OP) sebanyak 88.605 Orang. Hal ini menunjukkan bahwa tingkat kepatuhan WP OP di Kabupaten Bogor (KPP Cibinong dan KPP Cileungsi) hanya 44,88\%. Berdasarkan data yang ada Jumlah Wajib Pajak terdaftar di Kabupaten Bogor dari tahun 2008 hingga tahun 2011 mengalami penurunan. Hal ini dapat dilihat pada tabel berikut:

Tabel 1

Jumlah Wajib Pajak Orang Pribadi Tahun 2008 s/d 2011

\begin{tabular}{lcccc}
\hline No & Tahun & Jumlah Wajib Pajak & $\begin{array}{c}\text { Wajib Pajak Yang } \\
\text { Menyampaikan SPT }\end{array}$ & \% Kepatuhan \\
\hline 1 & 2008 & 96.550 & 61.286 & 63.48 \\
2 & 2019 & 145.388 & 81.910 & 56.34 \\
3 & 2010 & 171.148 & 85.744 & 50.10 \\
4 & 2011 & 197.434 & 88.605 & 44.88 \\
\hline
\end{tabular}

Berdasarkan tabel di atas maka dapat dilihat bahwa dari tahun 2008 hingga tahun 2011, tingkat kepatuhan Wajib Pajak Orang Pribadi (WP OP) di Kabuapten Bogor (KPP Cibinong dan Cileungsi) senantiasa menurun. Hal ini tentu membutuhkan suatu kajian dan faktor-faktor apa yang mempengaruhi agar hal tersebut tidak terjadi berlarut-larut. Kepatuhan yang dimaksud adalah sebagai suatu keadaan dimana wajib pajak memenuhi semua kewajiban perpajakan dan melaksanakan hak perpajakannya, Nurmantu (2003). Kepatuhan
Wajib Pajak dalam membayar pajak secara formal dapat dilihat dari aspek kesadaran wajib pajak untuk mendaftarkan diri, ketepatan waktu dalam membayar pajak dalam menyampaikan SPT tahunan, ketepatan waktu dalam membayar pajak dan pelaporan wajib pajak melakukan pembayaran pajak dengan tepat waktu. Kepatuhan material dalam mengisi SPT PPh adalah Wajib Pajak yang mengisi dengan jujur, baik dan benar atas SPT tersebut sehingga sesuai dengan ketentuan dalam Undang-undang perpajakan dan menyampaikan SPT ke KPP 
sebelum batas waktu.

\section{Telaah Teori dan Pengembangan Hipotesis}

Penelitaian tentang kepatuhan pajak banyak diungkapakan diantaranya:

Hardiningsih dan Yulianawati (2011), melakukan penelitian mengenai faktor-faktor yang mempengaruhi kemauan membayar pajak. Hasil penelitian Hardiningsih dan Yulianawati menyatakan bahwa sikap Wajib Pajak terhadap kesadaran Wajib Pajak berpengaruh signifikan terhadap membayar Pajak dan Kualitas layanan berpengaruh positif terhadap kemauan membayar pajak.

Widodo (2010), melakukan penelitian mengenai pengaruh Moralitas dan budaya pajak terhadap kepatuhan pajak di Indonesia. Hasil penelitian Widodo menyatakan bahwa Moralitas dan budaya pajak berpengaruh terhadap Kepatuhan Pajak baik secara parsial maupun silmutan.

Supriyati dan Hidayati (2008) melakukan penelitian mengenai pengaruh pengetahuan pajak dan persepsi wajib pajak terhadap kepatuhan wajib pajak. Hasil penelitian Supriyati dan Hidayati menyatakan bahwa Pengetahuan tentang pajak berpengaruh terhadap Kepatuhan Wajib Pajak. Persepsi tentang petugas pajak tidak berpengaruh terhadap Kepatuhan Pajak.

Mustikasari (2007), melakukan penelitian mengenei kajian impiris tentang kepatuhan wajib pajak badan di perusahaan industri pengolahan di Surabaya

Jatmiko (2006), melakukan penelitian mengenei kajian empiris pengaruh sikap wajib pajak pada pelaksanaan sanksi denda, pelayanan fiskus dan kesadaran perpajakan terhadap kepatuhan wajib pajak di kota Semarang. Hasil penelitian Jatmiko menyatakan bahwa Sikap Wajib Pajak terhadap pelaksanaan sanksi denda, sikap Wajib Pajak terhadap pelayanan Fiskus dan siksp Wajib Pajak terhadap kesadaran perpajakan memiliki pengaruh postif yang sinifikan terhadap Kepatuhan Wajib Pajak.

Kahono (2003), melakukan penelitian mengenai pengaruh sikap Wajib Pajak terhadap Kepatuhan Wajib Pajak dalam pembagunan pajak bumi dan bangunan di KP PBB Semarang. Hasil penelitian dari Kahono menyatakan bahwa Sikap Wajib Pajak terhadap pelayanan fiskus dan sikap wajib Pajak bahwa penghidaran Pajak PBB pengaruh postif yang signifikan terhADAP Kepatuhan Wajib Pajak.

\section{Metode Penelitian}

Penelitian ini dilakukan di Kantor Pelayanan Pajak Pratama Cileungsi yang beralamat di Jl. Raya Pemda No.39, Cibinong dan Kantor Pelayanan Pajak Pratama Cibinong yang beralamat di Jl. Aman No.1, Komplek Pemda Kabupaten Bogor. Jenis data yang digunakan dalam penelitian ini, yaitu data subjektif yang diperoleh dengan menyebarkan kuesioner kebeberapa responden dengan targetnya Wajib Pajak Orang Pribadi di Kantor Pelayanan Pajak di Kabupaten Bogor. Berdasarkan sumbernya, data dibedakan menjadi dua yaitu: (1) Data primer adalah data yang diperoleh dari responden secara langsung dari sumber data yang dikumpulkan melalui survai lapangan dengan menggunakan alat pengumpulan data tertentu yang dibuat secara khusus untuk itu. dan data dalam penelitian ini diambil dari jawaban kuesioner, (2) Data sekunder adalah data yang telah dikumpulkan oleh pihak lain atau lembaga pengumpul data dan dipublikasikan kepada masyarakat pengguna data. (Sugiyono, 2012). seperti buku, jurnal, media internet dan penelitian terdahulu.

Populasi adalah wilayah generalisasi yang terdiri atas obyek/ subyek yang mempunyai kualitas dan karekteristik tertentu yang ditetapkan oleh peneliti untuk dipelajari dan kemudian ditarik kesimpulannya Sugiyono (2012). Populasi dalam penelitian ini adalah Wajib Pajak Orang Pribadi (WP OP) yang ada di Kabupaten Bogor. Berdasarkan data dari KPP yang ada di Kabupaten Bogor (KPP Pratama Cileungsi dan KPP Pratama Cibinong), hingga akhir tahun 2011 tercatat sebanyak 197.434 WP OP yang merupakan WP OP yang wajib lapor. Tidak semua Wajib Pajak Orang Pribadi (WP OP) yang wajib lapor ini menjadi obyek dalam penelitian ini. Oleh sebab itu dilakukan pengambilan sampel dengan keriteria wajib Pajak orang pribadi yang melakukan usaha bebas dan Profesional.

Metode penarikan sampel yang digunakan dalam penelitian ini adalah metode proportional sampling. Untuk menghitung jumlah sampel yang dapat digunakan dalam penelitian ini, maka penulis menggunakan rumus Slovin dalam (Umar, 2004) sebagai berikut: 


$$
n=\frac{N}{N \cdot e^{2}+1}
$$

Keterangan :

$\mathrm{n}=$ jumlah sampel

$\mathrm{N}=$ jumlah populasi $=197.434$ orang

$\mathrm{e}=\operatorname{error}($ maksimal sebesar $10 \%)=0,1$

$$
\begin{aligned}
n & =\frac{197.434}{197.434 \cdot(10 \%)^{2}+1} \\
& =99,99=100
\end{aligned}
$$

Analisis data dalam penelitian ini menggunakan SEM. Menurut Ghozali dan Fuad (2008), ukuran minimal sampel untuk dapat diuji dengan menggunakan Structural Equation Modeling (SEM) adalah 100. Sedangkan menurut Hair et al. (2006) menyarankan agar ukuran jumlah sampel minimal untuk analisis SEM adalah 100 sampai 200, atau sebanyak 5-10 kali jumlah parameter yang diestimasi (Jerskog dan Sorbon, dalam Ferdinand, 2006). Agar memenuhi syarat untuk dilakukannya pengujian data dengan menggunakan SEM, maka jumlah sampel yang diambil sebanyak 200 orang responden. Perhitungan jumlah sampel yang diambil untuk setiap KPP berdasarkan proportional sampling adalah sebagai berikut :

Tabel 2.

Perhitungan Pengambilan Sampel Untuk Setiap KPP

\begin{tabular}{lccc}
\hline No & KPP & $\begin{array}{c}\text { Jumlah WP OP } \\
\text { Yang Menyampaikan } \\
\text { SPT }\end{array}$ & $\begin{array}{c}\text { Jumlah } \\
\text { Sampel }\end{array}$ \\
\hline 1 & Pratama Cileungsi & 47.208 & 48 \\
2 & Pratama Cibinong & 150.226 & 152 \\
\hline
\end{tabular}

Metode pengumpulan data pada penelitian ini menggunakan kuesioner (sebagai alat pengumpulan data), yaitu memperoleh data dengan cara mengajukan daftar pernyataan tertulis secara lengkap tentang masalah yang akan dibahas kepada para responden. Sedangkan pengumpulan data sekunder dilakukan dengan metode dokumentasi.
Tabel 3.

Skala Penilaian

\begin{tabular}{llc} 
No & Alternative Jawaban & Bobot Skor \\
\hline 1 & SS = Sangat Setuju & 5 \\
2 & S = Setuju & 4 \\
3 & KS = Kurang Setuju & 3 \\
4 & TS = Tidak Setuju & 2 \\
5 & STS = Sangat Tidak Setuju & 1 \\
\hline
\end{tabular}

Variabel terikat dalam penelitian in adalah Kepatuhan Pajak, sedangkan variabel bebas adalah Faktor penggelapan Pajak, Interaksi Fiskus dengan Wajib Pajak. Masing-masing definisi operasional variabel akan dijelaskan sebagai berikut:

1. Kepatuhan Pajak, menurut Nurmantu, 2003 yaitu:

a. Kepatuhan formal adalah suatu keadaan dimana wajib pajak memenuhi kewajibannya secara formal sesuai dengan dengan ketentuan dalam undangundang perpajakan. Kepatuhan wajib pajak dalam membayar pajak secara formal dapat dilihat dari aspek kesadaran wajib pajak untuk mendaftarkan diri, ketepatan waktu dalam membayar pajak dalam menyampaikan SPT tahunan, ketepatan waktu dalam membayar pajak dan pelaporan wajib pajak melakukan pembayaran pajak dengan tepat waktu.

b. Kepatuhan Material adalah suatu keadaan dimana wajib pajak secara substantif (hakikat) memenuhi semua ketentuan material perpajakan yakni sesuai isi dan jiwa undang-undang perpajakan. Jadi wajib pajak yang memenuhi kepatuhan material dalam mengisi SPT PPh adalah wajib pajak yang mengisi dengan jujur, baik dan benar atas SPT tersebut sehingga sesuai dengan ketentuan dalam Undangundang perpajakan dan menyamapikan SPT ke KPP sebelum batas waktu. Indikator Kepatuhan pajak ini di antaranya: pendaftaran wajib pajak, penyampaian SPT, pembayaran pajak, pelaporan pembayaran pajak, kesesuaian jumlah kewajiban pajak yang harus dibayar dengan perhitungan sebenarnya, penghargaan terhadap independensi akuntan publik konsultan pajak dan jumlah tunggakan pajak. 
Variabel kepatuhan pajak diukur dengan skala likert dengan 5 poin untuk 8 pertanyaan.

2. Faktor penggelapan Pajak yaitu: Penghindaran pajak secara ilegal/ penggelapan pajak (tax evasion) yaitu wajib pajak tidak melaporkan secara utuh kekayaan dan penghasilannya yang semestinya kena pajak. Tindakan demikian dapat dikenakan hukuman. Hal ini dimungkinkan dapat terjadai karena kurangnya pengawasan dari fiskus.Alm et.al,(2001) menyebutkan bahwa kemungkinan wajib pajak akan diperiksa justru akan berpengaruh dari pada sanksi administrasi karena wajib pajak mengetahui bahwa otoritas pajak tidak akan melakukan seleksi secara acak kepada wajib pajak yang akan diperiksa, akan tetapi menggunkan informasi dari SPT yang disampaikan wajib pajak untuk menentukan pemeriksaan. Selain sanksi administrasi dan kemungkinan dilakukan audit, yang menjadi alasan mengapa wajib pajak enggan untuk melakukan penghindaran pajak atau pengelakan pajak adalah kualitas layanan publik yang mereka peroleh serta kemungkinan wajib pajak dalam melakukan kewajiban perpajakannya dengan didukung oleh rendahnya biaya-biaya maupunpungut apabila mereka melakukan kewajiban secara benar dan tepat.

Indikator Faktor penggelapan pajak ini adalah: pemeriksaan pajak, Sanksi administrasi dan pidana, Kualitas layanan publik, Ekonomi biaya tinggi. Variabel pengelakan pajak ini diukur dengan skala likert dengan 5 poin untuk 8 pertanyaan.

3. Interaksi fiskus dengan wajib pajak adalah hubungan antara aparatur pajak dengan wajib pajak dapat berupa hubungan yang bersifat administratif dalam artian berkaitan dengan tugas dan tanggung jawab aparatur pajak terhadap wajib pajak maupun hubungan yang bersifat informal Widodo (2010). Dalam hal ini indikatornya sebagai berikut: tingkat kemampuan petugas pajak dalam melayani permasalahan perpajakan, tingkat ketanggapan dan kecepatan petugas pajak dalam melayani permasalahan perpajakan, tingkat perhatian petugas pajak dalam melayani permasalahan perpajakan.

Variabel interaksi fiskus dengan wajib pajak diukur dengan skala likert 5 poin untuk 3 pertanyaan.

Berikut ini dapat dilihat ringkasan definisi operasional yang digunakan dalam penelitian ini.

Tabel 4.

Definisi Operasional Variabel, Indikator, Pengukuran Sumber

\begin{tabular}{|c|c|c|c|c|}
\hline Variabel & $\begin{array}{l}\text { Konsep } \\
\text { Variabel }\end{array}$ & Indikator & Skala & Pernyataan \\
\hline $\begin{array}{l}\text { Faktor } \\
\text { Penggelapan } \\
\text { Pajak } \\
\text { (X1) }\end{array}$ & $\begin{array}{l}\text { Kesadaran } \\
\text { WP untuk } \\
\text { melaksanakan } \\
\text { kewajiban } \\
\text { pajak Widodo } \\
(2010)\end{array}$ & $\begin{array}{l}\text { - Pemeriksaan } \\
\text { pajak } \\
\text { - Sanksi } \\
\text { administrasi } \\
\text { - Kualitas } \\
\text { layanan } \\
\text { publik } \\
\text { - Biaya tinggi }\end{array}$ & $\begin{array}{l}\text { Ordinal dengan • } \\
\text { teknik skala } \\
\text { likert, luntuk } \\
\text { STS hingga } 5 \\
\text { untuk SS } \\
\bullet \\
\bullet\end{array}$ & $\begin{array}{l}\text { - Saya mengetahui kalau tidak } \\
\text { membayar pajak dapat dikenai } \\
\text { sanksi administrasi dan pidana } \\
\text { - Saya tidak mau membayar pajak } \\
\text { karena terlalu ringan sanksi } \\
\text { administrasi } \\
\text { - Saya mau membayar pajak } \\
\text { karena sering ada pemeriksaan } \\
\text { pajak } \\
\text { - Saya mau membayar pajak } \\
\text { karena takut dengan adanya } \\
\text { pemeriksaan pajak oleh } \\
\text { pemeriksa kantor pajak } \\
\text { Saya membayar pajak karena } \\
\text { pajak bermanfaat untuk } \\
\text { pelayanan publik } \\
\text { Saya membayar pajak karena } \\
\text { kualitas pelayanan umum yang }\end{array}$ \\
\hline
\end{tabular}




\begin{tabular}{|c|c|c|c|}
\hline $\begin{array}{l}\text { Interaksi } \\
\text { fiskus } \\
\text { dengan } \\
\text { wajib pajak } \\
\text { ( X2) }\end{array}$ & $\begin{array}{l}\text { - Aparatur } \\
\text { pajak } \\
\text { diharapkan } \\
\text { memiliki } \\
\text { sikap yang } \\
\text { simpatik, } \\
\text { mudah } \\
\text { dihubungi } \\
\text { dan jujur } \\
\text { dalam } \\
\text { hubungan } \\
\text { dengan WP } \\
\text { Widodo } \\
\text { (2010) }\end{array}$ & $\begin{array}{l}\text { - Kemampuan } \\
\text { petugas } \\
\text { pajak dalam } \\
\text { melayani } \\
\text { permasalahan } \\
\text { perpajakan } \\
\text { - Ketangggapan } \\
\text { dan kecepatan } \\
\text { petugas } \\
\text { pajak dalam } \\
\text { melayani } \\
\text { permasalahan } \\
\text { perpajakan } \\
\text { Perhatian } \\
\text { petugas } \\
\text { pajak dalam } \\
\text { melayani } \\
\text { permasalahan } \\
\text { perpajakan }\end{array}$ & $\begin{array}{l}\text { Ordinal } \\
\text { dengan } \\
\text { tehnik skala } \\
\text { likert 1, } \\
\text { untuk STS } \\
\text { hungga 5, } \\
\text { untuk SS }\end{array}$ \\
\hline $\begin{array}{l}\text { Kepatuhan } \\
\text { pajak (y) }\end{array}$ & $\begin{array}{l}\text { - Kepatuhan } \\
\text { Formal: } \\
\text { Kepatuhan } \\
\text { Wp dalam } \\
\text { memenuhi } \\
\text { kewajibannya } \\
\text { sesuai } \\
\text { Undang- } \\
\text { undang } \\
\text { perpajakan } \\
\text { yang berlaku. } \\
\text { Numantu } \\
\text { dalam } \\
\text { Widodo } \\
\text { (2010) } \\
\text { Kepatuhan } \\
\text { Material: } \\
\text { keadaan WP } \\
\text { memenuhi } \\
\text { semua } \\
\text { ketentuan } \\
\text { material } \\
\text { perppajakan } \\
\text { Widodo } \\
\text { (2010) }\end{array}$ & $\begin{array}{l}\text { - Pendaftaran } \\
\text { wajib pajak } \\
\text { - Penyampaian } \\
\text { SPT } \\
\text { - Pembayaran } \\
\text { Pajak } \\
\text { - Pelaporan } \\
\text { pajak } \\
\text { - Kesesuaian } \\
\text { jumlah } \\
\text { kewajiban } \\
\text { pajak yang } \\
\text { harus dibayar } \\
\text { dengan } \\
\text { perhitungan } \\
\text { sebenarnya } \\
\text { Penghargaan } \\
\text { terhadap } \\
\text { independensi } \\
\text { akuntansi } \\
\text { publik } \\
\text { konsultan } \\
\text { pajak } \\
\text { - Jumlah } \\
\text { tunggakan } \\
\text { Frekuensi } \\
\text { pajak }\end{array}$ & $\begin{array}{l}\text { Ordinal } \\
\text { dengan } \\
\text { tehnik skala } \\
\text { likert 1, } \\
\text { untuk STS } \\
\text { hingga 5, } \\
\text { untuk SS }\end{array}$ \\
\hline
\end{tabular}

saya rasakan sudah baik

- Saya tidak mau membayar pajak karena adanya pungutan tidak resmi selain pajak cukup tinggi

- Saya selalu berusaha menghindar pajak karena biaya untuk menyuap petugas pajak masih lebih kecil dibandingkan dengan penghematan pajak

- Menurut saya petugas pajak sangat mampu dalam melayani permasalahan perpjakan wajib pajak

- Menurut saya petugas pajak cepat dan tanggap dalam melayani permasalahan perpjakan

- Menurut saya petugas pajak sangat perhatian kepada wajib pajak dalam permasalahan perpajakan

- Menurut saya petugas pajak sangat ramah dalam melayani wajib pajak

- Menurut saya aparat pajak sangat mudah dalam melakukan hubungan, komunikasi yang baik dan memahami kebutuhan wajib pajak

- Saya mau mendaftarkan diri sebagai wajib pajak karena taat pada peraturan Perundangundangan perpajakan

- Saya mau mendaftarkan diri sebagai wajib pajak karena takut akan adanya sanksi perpajakan

- Saya selalu tepat waktu dalam penyampaian SPT ke kantor pajak

- Saya selalu tepat waktu dalam membayar pajak

- Saya selalu tepat waktu dalam menyetorkan pajak

- Saya membayar pajak sesuai dengan perhitungan pajak yang sebenarnya

- Dalam membayar pajak saya percayakan kepada konsultan pajak dan saya tidak mempengaruhi perhitungan dari konsultan pajak

- Saya mau membayar pajak tergantung besar kecilnya tunggakan pajak (hutang pajak) 
Data yang diperoleh dari hasil penyebaran kuesioner kemudian diolah untuk menguji hipotesis yang diteliti. Tahapan-tahapan yang dilakukan dalam pengolahan data tersebut adalah sebagai berikut:

1. Tahap editing, yaitu melakukan screening questions (hanya responden yang memenuhi karakteristik yang telah ditentukan yang akan diolah datanya), kemudian pemeriksaan atas jawaban yang telah diperoleh dari responden untuk mengetahui apakah jawaban yang diberikan telah sesuai dengan petunjuk pengisian kuesioner. Tahap ini dilakukan dengan cara mengoreksi jawaban satu persatu.

2. Tahap tabulasi, yaitu pemberian skor/nilai terhadap jawaban responden berdasarkan skala Likert.

3. Tahap pengolahan data, dalam penelitian ini akan dilakukan pengolahan data dengan menggunakan Structural Equation Modeling (SEM) dengan Lisrel 8.54

\section{Uji Validitas dan Reliabilitas}

Uji validitas dilakukan untuk mengetahui apakah alat ukur yang telah disusun dapat digunakan untuk mengukur apa yang hendak diukur secara tepat. Validitas suatu instrumen menggambarkan tingkat kemampuan alat ukur yang digunakan untuk mengungkapkan sesuatu yang menjadi sasaran pokok pengukuran. Bila instrumen tersebut mampu untuk mengukur variabel yang diukur maka disebut sebagai valid, dan sebaliknya apabila tidak mampu untuk mengukur variabel yang diukur maka akan disebut tidak valid (Sekaran, 2006). Pengujian validitas instrumen menggunakan variance extracted dengan nilai minimal 0,50
(Hair, et,al,. 2006). Variance extracted diperoleh dari nilai loading factor hasil analisis SEM. Jika variance extracted lebih besar dari 0,50 maka item pernyataan dinyatakan valid.

Reliabilitas instrumen menggambarkan pada kemantapan dan keajegan alat ukur yang digunakan. Suatu alat ukur dikatakan memiliki reliabilitas atau keajegan yang tinggi atau dapat dipercaya, apabila alat ukur tersebut stabil sehingga dapat diandalkan (dependability) dan dapat digunakan untuk meramalkan (predictability) (Sekaran, 2006). Perhitungan reliabilitas dalam penelitian ini yaitu dengan melihat construct reliability yang memiliki nilai-nilai cut off value minimal sebesar 0,70 (Hair, et,al,. 2006). Rumus construct reliability dituliskan sebagai berikut:

$$
C R=\text { Construct Reliability }=\frac{(\Sigma \text { std. loading })^{2}}{(\Sigma \text { std. loading })^{2}+\sum \vartheta}
$$

Standard loading diperoleh dari standardized loading untuk tiap-tiap indikator yang didapat dari hasil Output Lisrel. $\vartheta$ adalah measurement error dari tiap indikator.

\section{Analisis Struktural Equation Modeling (SEM)}

Langkah-langkah analisis SEM adalah sebagai berikut:

1. Mengembangkan model dan merespesifikasi model pengukuran

Penelitianini menggunakan tiga pengukuran, yaitu Penggelapan pajak, Interaksi fiskus dengan wajib pajak dan kepatuhan pajak yang akan digambarkan dalam bentuk path diagram.

Diagram jalur yang menggambarkan keterkaitan antar variabel penelitian dapat dilihat pada gambar 3.1 berikut ini.

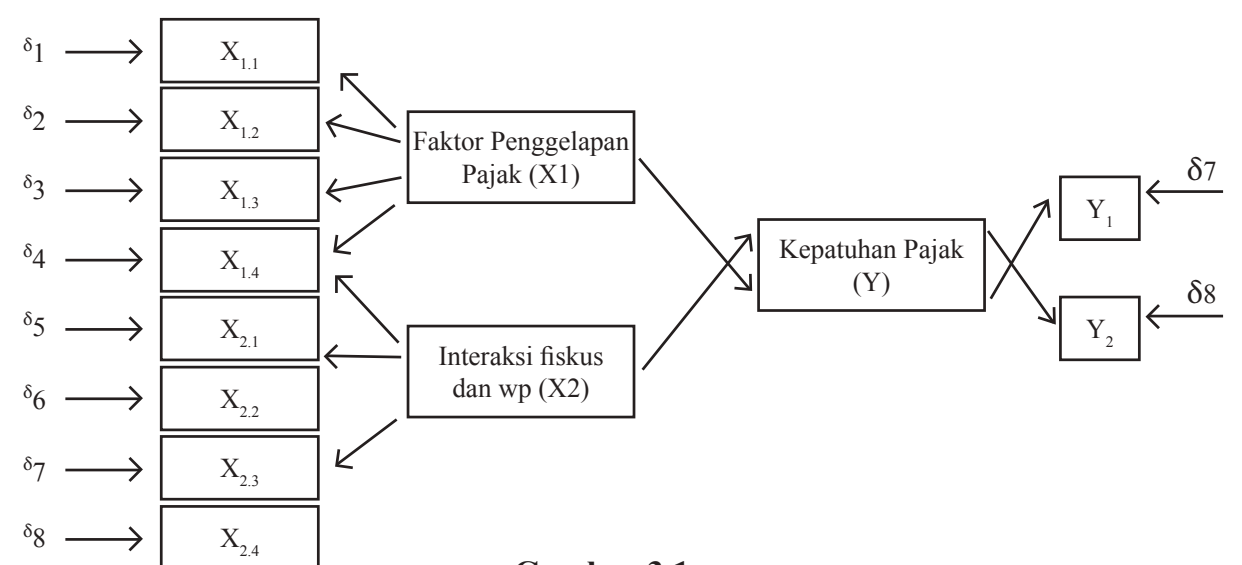

Gambar 3.1

Paradigma Penelitian 
Merumuskan Persamaan

Model penelitian d iatas pada hakikatnya memperlihatkan bahwa faktor Pengelakan Pajak (X1) dan Interkasi Fiskus dengan Wajib Pajak ( X2) adalah variabel eksogen yang secara langsung mempengaruhi Kepatuhan Pajak sebagai konsekuensi yang disebut sebagai variabel endogen sesuai dengan persamaan model matematis berikut: $\mathrm{Y}=\mathrm{I}$ 'X1+I'X2 $+\mathrm{r}$

Confirmatory Factor Analysis (CFA), bertujuan untuk mengetahui apakah indikatorindikator yang ada sudah dapat menlaskan sebuah konstruk dalam penelitian (Hair, 2006). Untuk mengetahui overall model fit akan dievaluasi pengujian dengan kriteria fit indices sebagai berikut :

a. CMIN/df atau normed Chi-square dengan kriteria nilai $1<\mathrm{CMIN} / \mathrm{df}<3$. Nilai diantara 2 sampai dengan 3 masih termasuk dalam batas atas yang disarankan, mengindikasikan satisfactory fit. Nilai CMIN/df yang mendekati 1 mencerminkan bahwa good fit, sedangkan nilai CMIN/df < 1 mengindikasikan overfit (Wijanto, 2008 serta Smith et al., 2006).

b. Goodness of Fit Indices (GFI)

Nilai ini akan menunjukkan derajat kesesuaian dari keseluruhan model. Alat uji ini memungkinkan pengaruh jumlah sampel menjadi kurang sensitif dalam proses pengambilan keputusan, yang merupakan kelemahan dari alat uji Chi-square. Nilai GFI berkisar antara 0 sampai dengan 1, semakin tinggi akan semakin baik. Nilai GFI yang lebih besar dari 0.95 mengindikasikan good fit, $0.90 \leq \mathrm{GFI} \leq 0.95$ mengindikasikan satisfactory fit, sedangkan $0.80 \leq \mathrm{GFI}<0.90$ mengindikasikan marginal fit.(Wijanto, 2008; Hair, 2006; Smith et al, 2006; serta Santoso, 2007).

c. Adjusted Goodness of Fit Indices (AGFI)

Nilai ini merupakan penyesuaian dari nilai GFI dalam hal memperhitungkan tingkat kompleksitas model, dengan memasukkan pengaruh degree of freedom dalam pengujian. Seperti layaknya GFI, nilai AGFI berkisar antara 0 sampai dengan 1, semakin tinggi semakin baik. AGFI lebih besar dari 0.95 mengindikasikan good fit, $0.90 \leq \mathrm{AGFI} \leq 0.95$ mengindikasikan satisfactory fit sedangkan $0.80 \leq$ AGFI < 0.90 mengindikasikan marginal fit (Wijanto, 2008; Hair et al., 2006; Smith et al., 2006; serta Santoso, 2007).

d. Root Mean-Square Error of Appriximation (RMSEA)

Nilai ini merupakan alat ukur alternatif yang dapat mengatasi kelemahan dari chisquare GOF yang cenderung menolak model dengan jumlah sampel dan atau jumlah variabel teramati yang besar. Nilai RMSEA kurang dari sama dengan 0.08 mengindikasikan good fit. Jika nilai RMSEA kurang dari 0.05, maka dapat dianggap close fit (Wijanto, 2008 serta Hair et al., 2006).

e. Comparative Fit Indices (CFI)

Nilai ini merupakan alat ukur yang paling banyak digunakan karena keunggulannya yang relatif tidak sensitif terhadap tingkat kompleksitas model. Nilai CFI berkisar antara 0 sampai dengan 1 , dengan nilai lebih tinggi lebih baik. Nilai CFI lebih besar dari 0.95 mengindikasikan good fit. Namun demikian nilai CFI yang berada diantara 0.90 sampai dengan 0.95 masih mengindikasikan satisfactory fit. Nilai CFI mendekati 0 mengindikasikan poor fit, sementara nilai $\mathrm{CFI}=1$ mengindikasikan perfect fit (Hair et al, 2006 serta Smith et al., 2006).

f. Uji construct validity melalui pengujian convergent validity dan uji discriminant validity. Kedua pengujian ini dilakukan untuk menguji validitas konstruk dan dilakukan setelah data dianggap fit dengan model pengukuran. Pada uji convergent validity akan dilihat nilai factor loading dan internal consistency reliability untuk mengetahui apakah indikator-indikator yang ada pada sebuah konstruk benar-benar dapat menjelaskan konstruk tersebut dan indikatorindikator tersebut merefleksikan kesamaan konstruk. Nilai factor loading lebih dari 0.5 ataunilai positif serta signifikansi kurang dari 0.05, mengindikasikan indikator dianggap merupakan bagian dari konstruk (Hair et al., 2006 serta Santoso, 2007), sementara nilai Cronbach's Alpha $\geq 0.6$ membuktikan bahwa seluruh indikator merefleksikan kesamaan konstruk (Malhotra, 2007). Sedangkan pada uji discriminant validity akan dilihat bagaimana satu konstruk dan konstruk lainnya dalam model pengukuran saling berbeda (Santoso, 2007). Jika nilai correlations < square variance extracted, maka hubungan antar konstruk adalah lemah atau dapat dikatakan setiap konstruk dapat dibedakan (Fornell, Tellis dan Zinkhan, 
1982 dalam Hanlon, 2001).

g. Pengujian overall model fit dari model struktural. Untuk mengetahui overall model fit dari model struktural, akan dievaluasi tingkat kecocokan yang diperoleh melalui pengujian dengan kriteria fit indices yang sama seperti kriteria pengujian overall model fit pada model pengukuran yang telah dijelaskan sebelumnya (Santoso, 2007).

h. Multiple Regression Analysis yang digunakan untuk menguji model struktural untuk mengetahui signifikansi dan kuat hubungan antara variabel eksogen/ independen dengan variabel endogen/ dependen (Santoso, 2007).

\section{Hasil Penelitian dan Pembahasan}

Dalam penelitian ini, data diperoleh melalui kuesioner yang diberikan kepada Wajib Pajak Pribadi yang menjalankan Usaha bebas dan Profesional di KPP Cibinong dan KKP Cileungsi Kabupaten Bogor. Kuesioner yang disebarkan kepada responden sebanyak 200 orang, kuesioner yang kembali 157. Jadi jumlah data yang dianalisis sebanyak 157. Pengumpulan data dalam penelitian ini dilakukan selama kurang lebih 5 bulan terhitung bulan Maret sampai Agustus 2013. Karakteristik responden terdiri dari usia, jenis kelamin, jenis usaha pekerjaan bebas, tingkat pendidikan terakhir, dan pendapatan. Data tersebut terkumpul dari hasil survey terhadap 157 responden yang merupakan Wajib Pajak Orang Pribadi yang menjalankan usaha bebas di wilayah KPP Cibinong dan KPP Cileungsi Kabupaten Bogor. Penjabaran karakteristik responden seperti tabel 3.1 dan tabel 3.2. berikut:

Tabel 5.

Karakteristik Responden Berdasarkan Usia, Jenis Kelamin dan Jenis Usaha

\begin{tabular}{lcc}
\hline Keterangan & Jumlah & Persentase \\
\hline USIA & & \\
Kurang dari 30 Tahun & 9 & $6 \%$ \\
31 - 40 Tahun & 35 & $22 \%$ \\
41 - 50 Tahun & 57 & $36 \%$ \\
51 - 55 Tahun & 46 & $29 \%$ \\
Lebih dari 55 Tahun & 10 & $7 \%$ \\
Total & 157 & $100 \%$
\end{tabular}

\section{Jenis Kelamin}

$\begin{array}{lrc}\text { Laki-Laki } & 91 & 58 \% \\ \text { Perempuan } & 66 & 42 \% \\ \text { Total } & 157 & 100 \%\end{array}$

\section{Jenis Usaha}

$\begin{array}{lcl}\text { Dokter } & 40 & 26 \% \\ \text { Notaris } & 37 & 23 \% \\ \text { Pengacara } & 11 & 7 \% \\ \text { Dosen } & 30 & 19 \% \\ \text { Lainnya } & 39 & 25 \% \\ \text { Total } & 157 & 100 \%\end{array}$

\section{Pendidikan Terakhir}

$\begin{array}{lcl}\text { SMU/Sederajat } & 2 & 1 \% \\ \text { Diploma } & 19 & 12 \% \\ \text { S1 } & 76 & 48 \% \\ \text { S2 } & 56 & 36 \% \\ \text { S3 } & 4 & 3 \% \\ \text { Total } & 157 & 100 \%\end{array}$

\section{Pendapatan per bulan}

$\begin{array}{lcl}\text { 0-5 Juta } & 12 & 8 \% \\ \text { 6-10 Juta } & 45 & 29 \% \\ \text { 11-15 Juta } & 51 & 32 \% \\ \text { 16-20 Juta } & 30 & 19 \% \\ \text { 21-25 Juta } & 12 & 8 \% \\ \text { Lebih dari 25 Juta } & 7 & 4 \% \\ \text { Total } & 157 & 100 \%\end{array}$

Variabel kepatuhan Pajak yang diukur dengan 2 indikator yaitu Y1 dan Y2. Nilai koefsien loading dan t-hitung dari kedua indikator tersebut dapat dilihat pada tabel di atas. Nilai koefisien indikator pada variabel Interaksi Fiskus Wajib Pajak, nilai koefisien Y1 sebesar 3.09 dan R2 (0.85), sedangkan Y2 sebesar 1.91, t-hitung sebesar 9.68 dan R2 sebesar (0.76). Dari kedua indikator tersebut yang paling tinggi mengukur variabel Kepatuhan Pajak yaitu Y1 dengan nilai R2 sebesar 0.85 . Reliabilitas dari indikator dapat dilakukan dengan melihat nilai R-square (R2) dari indikator. Nilai R-square menjelaskan mengenai seberapa besar proporsi varians indikator yang yang dijelaskan oleh 
konstruk/laten sedangkan sisanya dijelaskan oleh oleh measurement error. Nilai R-square Penggelapan Pajak sebagai dijelaskan pada tabel di atas. Nilai R-square tertinggi pada indikator X14 sebesar $(0.81(81 \%)$ sedangkan sisanya $19 \%$ (100\%-81\%) oleh measuremen error. Hal ini berarti memiliki proporsi varians tertinggi yang dijleaskan oleh variabel Penggelapan Pajak. Pada tabel diatas nilai R-square indikator X2 Nilai yang tertinggi pada indikator X24 sebesar 0.78, hal ini berarti indikator X24 paling kuat mempengaruhi variabel Interaksi Fiskus dengan Wajib Pajak dibandingkan indikator yang lain. Nilai R-square indikator pada variabel Kepatuhan Pajak dapat dilihat pada tabel di di atas.

Untuk menguji hipotesis dengan memperhatikan nilai t-hitung dan t-tabel, apabila nilai t-hitung $>\mathrm{t}$ tabel (1.96) maka tolak hipotesis nol. Nilai koefisien regresi variabel Penggelapan Pajak ke Kepatuhan Pajak sebesar 0.39 dan nilai t-hitung sebesar 4.44. Karena nilai t-hitung $4.44>$ t-tabel (1.96) maka tolak hipotesis nol yang membuktikan bahwa terdapat pengaruh yang signifikan Penggelapan Pajak terhadap Kepatuhan Pajak. Nilai koefisien regresi variabel Interaksi Fiskus Wajib Pajak ke Kepatuhan Pajak sebesar 0.42 dan nilai t-hitung sebesar 4,57. Karena nilai t-hitung (4.57) > t-tabel (1.96) maka keputusan menolak hipotesis nol yang menyatakan bahwa terdapat hubungan yang signifikan Intetraksi Fiskus Wajib Pajak terhadap Kepatuhan Pajak.

Pengaruh secara simultan variabel Penggelapan Pajak dan Interaksi Fiskus Wajib Pajak terhadap Kepatuhan Pajak sebesar 0.49 dan t-hitung sebesar 4.88. Karena nilai t-hitung (4.88) > t-tabel (1.96) maka keputusanya menolak hipotesis nol yang membuktikan bahwa terdapat pengaruh secara simultan/ bersama-sama variabel Penggelapan Pajak dan Interaksi Fiskus Wajib Pajak terhadap Kepatuhan Pajak.

Nilai R-square yang didapat ini (0.49) menujukkan bahwa besarnya variasi pada variabel Kepatuhan Pajak mampu dijelaskan oleh variabel Penggelapan Pajak dan Interaksi Fiskus Wajib Pajak sebesar 49\%. Sedangkan sisanya sebesar 51\% (100\% - 49\%) dijelaskan oleh variabel lain diluar model.

\subsection{Pembahasan}

Hasil pengujian pertama, menunjukan bahwa faktor penggelapan pajak memiliki pengaruh yang sinigfikan terhadap kepatuhan pajak. Hal ini menunjukan bahwa semakin tinggi Wajib Pajak menggelapkan pajak maka semakin tinggi Wajib Pajak tidak patuh. Sebaliknya semakin rendah Wajib Pajak menggelapkan pajak maka semakin tinggi kepatuhan Wajib Pajak. Faktor yang paling besar mempengaruhi penggelapan pajak adalah biaya ekonomi tinggi (81\%), ini menunjukan bahwa semakin biaya hidup tinggi maka Wajib Pajak akan mendahulukan keperluan hidupnya sehari-hari dari pada kewajiban pajaknya. Pelenggaran pajak yang dilakukan oleh Wajib Pajak sebenarnya dipicu oleh sifat manusia yang tidak ingin kesejahteraannya berkurang. Hal ini bisa dipahami apabila biaya ekonomi tinggi maka Wajib Pajak akan menutup biayabiaya tersebut supaya kesejahteraanya tidak berkurang dengan jalan menggelapkan pajak. Faktor yang paling rendah mempengaruhi penggelapan pajak adalah kualitas layanan publik (46\%). Dalam hal ini dapat dipahami dalam pembayaran pajak manfaanya belum sepenuhnya dapat dirasakan oleh Wajib Pajak terutama fasilitas umum, misalnya kesehatan dan pendidikan murah yang diharapkan oleh masyarakat belum sepenuhnya dirasakan secara langsung. Atas dasar sifat manusia tersebut maka Wajib pajak menggelapkan pajak.

Selain faktor biaya ekonomi tinggi dan kualitas layanan publik, ada faktor lain yang dapat mempengaruhi penggelapan pajak diantaranya sanksi administrasi dan pidana sebesar (48\%) dan pengawasan sebesar (73\%). Hal tersebut mendukung penelitian yang dilakukan oleh Widodo (2010) yang menghasilkan bahwa kepatuhan Pajak dipengaruhi oleh moral dan budaya pajak, dan Mustikasari (2007) yang menghasilakan Sikap Terhadap Ketidakpatuhan Pajak berpengaruh positif dan signifikan terhadap Niat Tax Professional untuk Berperilaku Tidak Patuh, Kewajiban Moral berpengaruh negatif dan signifikan terhadap Niat Tax Professional untuk Berperilaku Tidak Patuh

Pengaruh Interaksi Fiskus dengan Wajib Pajak terhadap Kepatuhan Pajak

Hasil pengujian hipotesis menunjukan bahwa Interaksi fiskus dengan Wajib Pajak berpengaruh terhadap kepatuhan pajak secara signifikan. Dalam hal ini semakin Wajib Pajak berinteraksi dengan Fiskus maka semakin 
tinggi kepatuhan pajak atau sebaliknya semakin Fiskus menjauh dengan Wajib Pajak maka semakin rendah Kepatuhan Pajak. Faktor yang paling mempengaruhi adalah keramahan petugas pajak dalam melayani Wajib Pajak (78\%). Keramahan petugas pajak yang dimaksud adalah keramahan dari fiskus dalam melayani Wajib Pajak. Diharapkan fiskus memiliki kemampuan dalam melayani memiliki sikap yang ramah. Wajib Pajak diperlakukan seperti pelanggan dalam perusahaan sehingga tetap mau membayar pajak. Faktor yang paling rendah dalam interkasi fiskus dengan Wajib Pajak adalah kemampuan petugas pajak dalam melayani Wajib Pajaki (35\%). Hal ini terjadi karena Wajib Pajak dalam kemampuan perpajakan sudah mulai membaik karena informasi mengenai perpajakan sudah dapat diakses diinternet dan bahkan Wajib Pajak mengikuti pelatihan-pelatihan dalam perpajakan.

Dengan demikian maka seorang petugas pajak harus dapat melayani permasalahan Wajib Pajak dan akan menimbulkan rasa puas bagi Wajib Pajak sehingga interaksi antara pegawai pajak dengan Wajib Pajak mendorong mereka untuk i untuk patuh dalam pajak. Dalam kaitannya dengan dengan variabel Interkasi fiskus dengan Wajib Pajak, maka pendekatan yang dilakukan berhubungan dengan Wajib Pajak seperti pelayanan prima kepada Wajib Pajak, konsultasi, Wajib Pajak dalam hal perpajakan. Disamping Faktor keramahan petugas dalam melayani Wajib Pajak dan kemampuan petugas dalam melayani Wajib Pajak, ada faktor lain yang mempengaruhi interaksi fiskus dengan Wajib Pajak diantaranya ketanggapan dan kecepatan petugas dalam melayani Wajib Pajak sebesar (40\%) dan perhatiaan petugas pajak dalam melayani Wajib Pajak sebesar (39\%).

Hal tersebut mendukung penelitian yang dilakukan oleh Widodo (2010) yang menghasilkan bahwa kepatuhan Pajak dipengaruhi oleh moral dan budaya pajak, dan Jatmiko (2006) yang menghasilkan sikap WP terhadap pelaksanaan sanksi denda, sikap WP terhadap pelayanan fiskus dan sikap wajib pajak terhadap kesadaran perpajakan memiliki pengaruh positif yang signifikan terhadap kepatuhan WP. Namun tidak mendukung penelitian yang dilakukan oleh Supriyati dan Hidayati (2008) yang menghasilkan persepsi Wajib Pajak terhadap Petugas Pajak tidak memiliki pengaruh terhadap Kepatuhan Wajib Pajak. Perbedaan ini disebabkan yang dijadikan responden oleh peneliti terdahulu berada pada satu KPP yang sama sehingga mereka dilayani oleh petugas yang berasal dari instansi yang sama mengakibatkan adanya persmaan pandangan terhadap petugas pajak.

Pengaruh Faktor Penggelapan Pajak dan Interaksi Fiskus dengan Wajib Pajak terhadap Kepatuhan Pajak

Hasil pengujian menunjukan bahwa faktor penggelapan pajak dan interaksi fiskus dengan Wajib Pajak secara silmutan berpengaruh terhadap kepatuhan pajak sebesar 49\%. Hal ini berarti tinggi rendahnya kepatuhan pajak dipengaruhi secara nyata dan positif oleh tinggi rendahnya faktor penggelapan pajak dan intearksi fiskus dengan Wajib Pajak. Ini mempunyai arti semakin rendah Wajib Pajak menggelapkan pajak maka Wajib Pajak semakin patuh dan semakin tinggi hubungan anatra fiskus dengan Wajib Pajak maka Wajib Pajak semakin patuh pajak.

Berdasarkan hasil pengujian tersebut juga masih terdapat sekitar $51 \%$ pengaruh variabel lain ( diluar variabel penelitian) dalam meningkatkan kepatuhan pajak. Hal ini memperlihatkan bahwa selain faktor penggelapan pajak dan interaksi fiskus dengan Wajib Pajak, masih terdapat beberapa variabel yang mempengaruhi kepatuhan pajak bahkan prosentasenya lebih besar. Dalam hal kepatuhan pajak itu sendiri selain faktor penggelapan pajak dan interaksi fiskus dengan Wajib Pajak, kepatuhan formal yang ditekankan oleh Wajib pajak mencapai (85\%) dibandingkan kepatuhan material sebesar $(73 \%)$. Hal ini menunjukan Wajib Pajak melaksanakan kewajiban perpajakan hanya secara formal saja tanpa memperhatikan materialnya.

\section{Kesimpulan, Keterbatasan dan Implikasi Hasil Penelitian}

Berikut ini adalah kesimpulan dari penelitian ini :

1. Faktor Penggelakan Pajak terhadap Kepatuhan Pajak memilikipengaruh positif yang signifikan terhadap Kepatuhan. Hal ini menunjukkan bahwa semakin besar Wajib Pajak yang menggelapkan Pajak maka semakin Wajib Pajak tidak patuh atau sebaliknya semakin kecil Wajib 
Pajak yang menggelapakan pajak rendah maka semakin besar Kepatuhan pajak.

2. Interaksi Fiskus dengan Wajib Pajak secara parsial memiliki pengaruh positif yang signifikan terhadap kepatuhan Pajak. Hal ini menunjukkan semakin tinggi interkasi antara fiskus dengan Wajib Pajak semakin tinggi pula Kepatuhan Pajak.

3. Secara silmutan faktor Penggelapan Pajak dan Interaksi Fiskus dengan Wajib Pajak berpengaruh terhadap Kepatuhan Pajak. Ini berarti semakin interkasi Fiskus dengan Wajib Pajak denga jujur dan perhatiaan akan menimbulkan Wajib Pajak enggan untuk menggelapakan pajak sehingga memunkinkan Wajib Pajak akan patuh dalam perpajakan.

Adapun keterbatasan dalam penelitian ini adalah: Penelitian ini menngunakan sampel hanya dua KPP sehingga menurut peneliti masih kurang dan dapat ditambahkan sampel lebih luas lagi agar mendapatkan gambaran sifat Wajib Pajak yang lebih luas., kurangnya variabel bebas yang digunakan sehingga secara silmutan pengaruh variabel bebas terhadap variabel terikat lebih kecil dibandingkan variabel diluar dalam penelitian. Berdasarkan hasil penelitian ini, maka peneliti menyarankan sebagai berikut:

1. Untuk meningkatkan Kepatuhan Pajak diharapkan Fiskus harus ramah dalam melayani Wajib Pajak, mampu jujur sesuai tanggung jawabnya dan dapat dipercaya oleh Wajib Pajak.

2. Direktorat Jenderal Pajak diharapkan meningkatkan pengawasan terhadap Wajib Pajak. Hal ini dapat dilakukan supaya Wajib Pajak tidak menggelapkan pajak dan dimungkinkan Wajib Pajak akan patuh pajak.

3. Wajib Pajak diharapkan dapat meningkatkan kepatuhan pajak baik secara formal maupun secara material.

4. Peneliti yang tertarik untuk melakukan kajian di bidang yang sama dapat menambah wilyah KPP untuk sampel dan menambah variabel bebas yang sudah digunakan dalam penelitian ini, hal ini dapat dilakukan karena wilayah dan variabel yang dalam penelitian ini masih kurang.

\section{Daftar Pustaka}

Ferdinand Augusty, 2012, SEM Dalam Penelitian Manajemen. Semarang: BPUniversitas Diponegoro.

Ghozali, Imam, dan Fuad. 2008. Structural Equation Modeling: Teori, Konsep dan Aplikasi Dengan Program Lisrel 8.0. Semarang: Badan Penerbit UNDIP

Hair, J.F., Anderson, R.E., Tatham, R.L., dan Black, W.C. 2006. Multivariate Data Analysis. New Jersey: Prentice-Hall Upper Saddle River: NJ: Prentice Hall

Hardiningsih Pancawati, Yulianawati Nila, 2011, Faktor-Faktor yang Mempengaruhi kemauan Membayar Pajak. Jurnal Dinamika Keuangan dan Perbankan, 2011

Husein Umar. 2004. Metode Penelitian untuk Skripsi dan Tesis Bisnis. Cetakan ke-6. Jakarta: PT Raja Grafindo Persada.

Hutagaol John, 2007, Isu-Isu Kontemporer, Edisi Pertama. Graha Ilmu, Yogyakarta, 2007.

Jatmiko Agus Nugroha, 2006, Pengaruh Sikap Wajib Pajak pada Pelaksanaan Sanksi Denda, Pelayanan Fiskus dan Kesadaran Perpajakan terhadap Kepatuhan Wajib Pajak, Jurnal Tesis

Mustikasari Elia , 2007, Kepatuhan Wajib Pajak Badan (Kajian Empiris di Perusahaan Industri Pengolahan di Surabaya). Simposium Nasional Akuntansi X. Unhas Makassar, 2007.

Kahono Sulud, 2003, Pengaruh Sikap Wajib Pajak terhadap Kepatuhan Wajib Pajak dalam Pembayaran Pajak Bumi dan Bangunan (Studi Empiris Wilayah KP. PBB Semarang), Jurnal Tesis

Malhotra, Naresh K. 2007. Marketing Research: An Applied Orientation, 15 ed.

Nurmantu Safri, Pengantar Perpajakan, Edisi 3, Granit, Jakarta, 2005

Penerimaan Negara 2009-2012, Http:/www. pajak.go.id/contaent/penerimaan-negaradetail-2009-2012, diunduh, 18 Maret 2012

Peraturan Menteri Keuangan Nomor 235/ KMK.03/2003 tentang kriteria wajib pajak patuh dalam rangka pengembalian pendahuluan kelebihan pembayaran pajak

Sekaran Uma, Reseach Methods For Business, Edisi 4, Salemba Empat, Jakarta, 2006

Santoso Singgih, 2011. Structural Equation Modeling (SEM), Konsep dan Aplikasi dengan AMOS 18. Penerbit Elex Media 
Komputindo. Jakarta.

Sugiyono, Metodologi Penelitian Kuantitatif Kualitatif dan R\&D, Alfabeta, Bandung, 2012

Supriyati dan Hidayati Nur, 2008, Pengaruh Pengetahuan Pajak dan Persepsi Wajib Pajak terhadap Kepatuhan Wajib Pajak, Jurnal Akuntansi dan Teknologi Informasi, 2008

Undang - Undang Nomor 28 Tahun 2007 Pasal 32 ayat 3 Undang-Undang tentang KUP.

Widodo Widi, 2010, Moralitas, Budaya dan Kepatuhan Pajak, Alfabeta, Bandung, 2010.

Wijanto, Setyo Hari. 2008. Struktur Equation Modeling. Konsep dan Tutorial Dengan Lisrel 8.80. Edisi II. Penerbit Graha Ilmu. Jakarta. 